\title{
PRIKAZ 15. SKUPA DRUŠTVA BIBLIOTEKARA PRAVNIH I SRODNIH KNJIŽNICA U MOSTARU 13. I 14. LIPNJA 2019. GODINE - OKRUGLI STOL "FAKULTETSKE KNJIŽNICE U NASTAVI I NJIHOV POLOŽAJ NA FAKULTETU: OKVIR ZA PROMJENE"
}

Svake se godine u sklopu Međunarodnoga savjetovanja Aktualnosti građanskog i trgovačkog zakonodavstva i pravne prakse održava Okrugli stol Društva bibliotekara pravnih i srodnih biblioteka Jugoistočne Europe. Tema Okrugloga stola je bila "Fakultetske knjižnice u nastavi i njihov položaj na fakultetu: okvir za promjene". Međunarodno se savjetovanje održavalo u hotelu Mostar i otvoreno je u petak 14. lipnja u 10 sati pozdravnim govorima dekanice Pravnoga fakulteta Sveučilišta u Mostaru prof. dr. sc. Sabrine Horović i rektora Sveučilišta prof. dr. sc. Zorana Tomića.

Nakon svečanoga otvorenja knjižničari su se odvojili u manju dvoranu gdje se odvijao Okrugli stol. Pozdravni su govor održale domaćica, voditeljica Knjižnice Pravnoga fakulteta u Mostaru Ljiljanka Šunje i predsjednica Društva, voditeljica Knjižnice Pravnoga fakulteta Sveučilišta u Splitu, knjižničarska savjetnica Edita Bačić. Članovima Društva pridružile su se i gošće, voditeljica Sveučilišne knjižnice u Mostaru Marija Karačić, voditeljica knjižnice Medicinskoga fakulteta Štefica Dodik, voditeljica Knjižnice Filozofskoga fakulteta Sanja Ledić te Agronomskog fakulteta Marija Smiljanić koje su pokazale interes za djelovanje Društva i eventualno pridruživanje.

Prvo izlaganje održala je mr. sc. Blaženka Peradenić-Kotur, voditeljica Odjela korisničke službe Nacionalne i sveučilišne knjižnice, pod nazivom NSK - podrška Sveučilištu i visokoškolskim knjižnicama. Riječ je bila o povijesti i ulozi krovne nacionalne Knjižnice tijekom četiriju stoljeća njezina postojanja. Naime, 1607. godine isusovci su je osnovali na Gradecu, 1776. g. u sastavu je Kraljevske zagrebačke akademije i već tada podrška u nastavi. Godine 1816. počinje se prikupljati i bilježiti obvezni primjerak. Sveučilišnom knjižnicom postaje 1874. godine i njezina naglašena uloga dolazi do izražaja u visokoškolskoj nastavi. Tek početkom prošloga stoljeća, 1913. godine, biva smještena na Trg Marka Marulića u zgradu koja predstavlja rijedak spomenik secesijske arhitekture (danas je u toj zgradi smješten Državni arhiv). Godine 1995. seli se u novu modernu zgradu od $45.000 \mathrm{~m}^{2} \mathrm{u}$ koju je danas smješteno oko tri milijuna svezaka građe, a primijenjen je kombinirani otvoreni i zatvoreni pristup engleskoga tipa knjižnica za 21. stoljeće. Ovdje se prikuplja sve što se tiska u zemlji i što se tiče Republike Hrvatske, sva nacionalna građa. Fond je bogat još od Austro-Ugarske Monarhije i svakim danom postaje sve bogatiji. Nacionalna i sveučilišna knjižnica ima 13.809 registriranih korisnika, 25.229 virtualnih korisnika, a u 2018. godini zabilježena su 460.144 posjeta. Velik je broj korisnika usluga noćnoga rada - 15.204, ponajviše studenata i istraživača. Danas ih do 22 sata opslu-

Blanka Salatić, mag. iur., viša knjižničarka, Pravni fakultet Sveučilišta J. J. Strossmayera u Osijeku. Adresa e-pošte: sblanka@ pravos.hr. 
žuju pomoćni knjižničari, a nadalje čuvarska služba. Temeljne djelatnosti NSK-a određene su Zakonom o knjižnicama iz 2019. godine. Odjel korisničke službe radi na izgradnji sveučilišne zbirke prema Smjernicama iz 2017. Radi se na osiguranju pristupa informacijama i izvorima za potrebe stručnoga i znanstvenog rada, tematskom i bibliometrijskom pretraživanju. Prihvaćen je razvojni projekt NSK-a financiran sredstvima Europskog socijalnog fonda u iznosu od $85 \%$ sredstava i $15 \%$ sredstava Ministarstva znanosti i obrazovanja RH, što će znatno pridonijeti nabavi izdanja, publikacija i osiguranju dostupnosti elektroničkim izvorima znanstvenih i stručnih informacija. Modul softvera Aleph omogućuje umrežavanje i koordiniranje sastavnicama glede nabave obvezne i dopunske ispitne građe. Radi se i na održavanju radionica za ciljne skupine korisnika s tercijarnim obrazovanjem što je iznimno važno za znanstvenu zajednicu.

Odlukom Vlade RH Nacionalna i sveučilišna knjižnica bit će mjestom odakle će krenuti predsjedanje Republike Hrvatske Vijećem Europe iduće, 2020. godine. Upravo zbog tog događaja uređuje se $7.500 \mathrm{~m}^{2}$ prostora koji će se poslije koristiti za kongrese i druge susrete relevantne za Republiku Hrvatsku i Grad Zagreb.

U svome izlaganju kolegica Edite Bačić "Sudjelovanje knjižnice u radu fakultetskih tijela: prilike za partnerstvo i suradnju” analizirala je koliko aktualni Zakon o knjižnicama podupire knjižnice u sastavu. Govorila je o Standardima za visokoškolske knjižnice koji bi bili u skladu s današnjim potrebama i trendovima kako u nastavi tako i knjižničarstvu. Osim toga, govornica je istaknula koliko fakultetski akti mogu doprinijeti sinergiji nastave i usluga knjižnice, a sve radi poboljšanja zadovoljstva korisnika. Izravno sudjelovanje knjižničara u nastavi može doprinijeti znatno boljem snalaženju s informacijama i akademskim pisanjem. Standardi bi trebali propisati obvezan rad knjižničara sa studentima čime bi studenti stjecali određeni broj ECTS bodova, a još važnije vještine za budući rad u struci ili znanosti. Indirektno sudjelovanje u nastavi očituje se u izgradnji zbirki za studente vezane uz nastavni plan i program. Status knjižnice dolazi do izražaja u dioništvu u fakultetskim tijelima, uključivanju u povjerenstva za izdavačku djelatnost, uređivanje časopisa (studentskih i znanstvenih), dodjeljivanje identifikatora vezanih za ISBN ili ISSN. Svoj doprinos knjižnica može dati i u izradi podzakonskih akata, pravilnika, priručnika. Kolegica Bačić organizirala je i izvannastavne aktivnosti u smislu studijskih putovanja: vodila je studente u NSK, Hrvatski sabor, Hrvatsku akademiju znanosti i umjetnosti te kaznionice. Omogućiti organiziranje radionice o informacijskoj pismenosti, djelovanje na etički kodeks unutar institucije znak je povjerenja i uvažavanja knjižničnome djelatniku. Djelovanje je svakako obostrano te doprinosi kvaliteti i prepoznavanju institucije u zajednici. Sudjelovanje knjižničara na međunarodnim skupovima i mogućnost međunarodne suradnje može otvoriti nove vidike mjerodavnima $u$ instituciji te iznjedriti nove metode $u$ nastavi. Dani sveučilišta prilika su fakultetskoj knjižnici da se predstavi zajednici, a napose budućim studentima. Tako je predstavljena Knjižnica Pravnoga fakulteta u Splitu kao poticaj članovima Društva, kako sadašnjim tako i budućim.

Izlaganje predstavnice Slovenije i dosadašnje tajnice Društva Viollette Bottazzo odnosilo se na Standarde za specijalne knjižnice (2018.-2028.). Govorila je o nastanku prvih knjižnica te vrste 1962./1963. godine, prvome Zakonu o knjižnicama Slovenije iz 1962. g. te registraciji knjižnica, odnosno usustavljivanju djelatnosti. Vrlo važnom je istaknula i ulogu Centralne tehniške knjižnice Univerze v Ljubljani te njezinoj organizaciji i ustroju u nastanku stručnih standarda. Sekcija za specijalne knjižnice Zveze bibliotekarskih društev Slovenije ustanovlje- 
na je 1983., a 1985. održano je prvo savjetovanje o ulozi specijalnih knjižnica u društvenom i gospodarskom razvoju. Godine 1990. doneseni su prvi Standardi za specijalne knjižnice, a nakon gotovo dva desetljeća, tijekom kojih su se prilike i funkcioniranje knjižnica znatno izmijenili, bilo je nužno mijenjati i standarde koji se tiču knjižničarske struke. Stoga je gđa Bottazzo predstavila nove Standarde i naglasila njihovu važnost u evaluacijskoj djelatnosti, razvoju kadrova, statusu specijalnih knjižničara u matičnoj organizaciji. Naglasak je stavljen i na profil te kompetencije specijalnog knjižničara, komunikacijske vještine i sposobnost u interakciji s vodstvom u matičnoj organizaciji te alate za vrjednovanje rezultata i za uspješnost $u$ evaluacijskim postupcima. U prilogu Standarda su kvalitativni i kvantitativni pokazatelji svih čimbenika koji doprinose dobrome funkcioniranju i uspješnosti specijalnih knjižnica. Ovim izlaganjem regiji su predstavljene glavne smjernice Standarda i ukazano je na mogućnost njihova online pregledavanja te oni mogu poslužiti kao uzor zainteresiranoj stručnoj javnosti.

Glede primjera dobre prakse predstavljena je Knjižnica Pravnoga fakulteta Sveučilišta Josipa Jurja Strossmayera u Osijeku i njezino uspješno djelovanje u nastavnom procesu. Knjižnica je tijekom više od četiriju desetljeća pratila potrebe nastavnika i studenata, kao i trendove u knjižničarstvu i tehnološkom napretku društva u cjelini. Posebna se pozornost poklanja korisnicima s tercijarnim obrazovanjem i njihovim potrebama za aktualnom građom i informacijama. Uz studentsku populaciju nastojalo se prilagoditi i potrebama lokalne zajednice i omogućiti informiranje građana. U izlaganju su izneseni osnovni podaci o prostoru, opremljenosti, korisnicima i uslugama te evaluacijskim postupcima. Knjižnica u velikoj mjeri zadovoljava potrebe korisnika i iznimno je važno istaknuti da je riječ o najbolje ocijenjenoj fakultetskoj službi s obzirom na kvalitetu usluga, radnu etiku i razinu izvrsnosti, što potvrđuju vanjski audit, akreditacija i Samoanaliza. Doprinos je to svekolikog napora knjižničara koji izuzetno kvalitetno obavljaju svoj posao. Za buduće djelovanje Knjižnice, iznimno važna bit će primjena Standarda za visokoškolske knjižnice, ponajprije kad su posrijedi uvjetni prostor te oprema za građu i korisnike. O projektu namjenski građene zgrade Fakulteta sa svim pripadajućim prostorima svakako očekujemo da se očituju i knjižničari koji najbolje znaju kojim sadržajima treba raspolagati Knjižnica gledajući 50 godina unaprijed. Novi načini komunikacije ne smiju ni na koji način dovesti do ugroze fonda. Svjedoci smo prijepora oko $5 \mathrm{G}$ tehnologije koja nudi nove modele i usluge no prije svega moramo se upitati je li to dobro za opstanak čovjeka i treba li mu to sve doista. Knjižnice čuvaju znanje i to se ni u kojem slučaju ne smije zaboraviti. Mi knjižničari vjerujemo da će budućnost donijeti dobre stvari za Knjižnicu i sve koji ju trebaju, naravno uz razumijevanje i potporu akademske i lokalne zajednice.

Na sva izlaganja osvrnule su se kolegice gošće sa Sveučilišta u Mostaru te se raspravljalo o njima najvažnijim vidovima poslovanja što glede rada s korisnicima, što glede praćenja preko statistike nabave, korištenja građe, citatne analize. Smatramo važnim da smo ih zaintrigirali, zainteresirali da se Društvu priključe.

Kolegica iz Univerzitetske biblioteke "Svetozar Marković” u Beogradu Maja Đorđević osvrnula se na noćno radno vrijeme te potrebu boljeg funkcioniranja u skladu s potrebama korisnika. Ukazala na mogućnost daljnje suradnje s g. Pürnerom i potpore u održavanju idućeg skupa.

Sljedećega dana Skupa održana je izborna skupština Društva bibliotekara. Izvješće o radu Društva iznijela je dosadašnja predsjednica Edita Bačić te navela uključenost u IFLA-u, (Međunarodna federacija knjižničnih udruženja), SEELS, potporu Ministarstva kulture Okruglom stolu i druge potpore koje su relevantne za rad Društva. Posebno se osvrnula na potporu gos- 
podina Markovića koji je pokazao spremnost pomoći u nakladničkom smislu. Uslijedio je izbor novih tijela Društva te je izabrana nova predsjednica, kolegica Mirela Rožajac-Zulčić iz Biblioteke Pravnoga fakulteta Univerziteta u Sarajevu. Izabrani su i novi članovi Upravnoga odbora koji uz predsjednicu Društva sada čine članovi Edita Bačić (Pravni fakultet u Splitu), Natalija Orešek (Pravni fakultet u Mariboru), Nenad Milošević (Pravni fakultet u Nišu) i Blanka Salatić (Pravni fakultet u Osijeku). Nova je tajnica Društva Sanja Golijanin iz Tužiteljstva BiH u Sarajevu.

Društvu se odlučila priključiti gđa Vera Bjelogrlić, šefica Centra za sudsku dokumentaciju Visokog sudskog i tužilačkog vijeća Bosne i Hercegovine. Predstavila je mrežnu stranicu institucije iz koje dolazi te ukazala na važnost koju Centar ima za pravosuđe zemlje. Smatra da skupljanje pouzdanih informacija i objava izabranih sudskih odluka te modeli za kaznena, građanska i upravna područja imaju snagu argumenata za nižestupanjske sudove, ali i za Ustavni sud. Gospođa Bjelogrlić istaknula je i važnost stručnih publikacija, centara za edukaciju, učenja na daljinu za buduće dionike u pravosuđu, stručne suradnike, pripravnike, no i mentore za novoimenovane suce i tužitelje. Aktivna su dva entitetska centra u Banja Luci i Sarajevu.

Razmatrale su se mogućnosti izdanja Priručnika za pravne bibliotekare te donijeli planovi o aktivnostima Društva za 2019. i 2020. godinu. Nadamo se da će prilike dopustiti da Društvo svojim radom i ubuduće nastavi doprinositi onomu što je važno akademskoj i široj zajednici. 